\section{A CASE OF SHIP BERI-BERI ASSOCIATED WITH AN ERYTHEMATOUS ERUPTION.}

By T. K. MONRO, M.A., M.D. GlasG.,

PHYSICLAY TO THE GLASGOW ROXAT, INFIRMARY, AND PROFESSOR OF MEDLCINE IN ST. MUNGO'S COLLEGE, GLASGOW.

CASES of beri-beri are by no means uncommon in Glasgow, and, indeed, during part of the time when the subject of this narrative was under my care there were three other cases in my clinique. Some of these patients are Lascars who have acquired the disease in India or on vessels in which they have been sailing between Britain and India. Others are seamen who have landed after long voyages on sailing vessels; they may have come, for instance, from New Caledonia, bringing nickel ore to the Clyde to be smelted at Kirkintilloch, six miles from Glasgow. The patient in the present case, however, did not belong to either of these categories. $\mathrm{He}$ was a native of Iceland, aged 27 years, who was employed on a trawler, and who had been at sea since he was 14 years old. From November, 1906, to May, 1907, he was fishing off the coast of Morocco, but he never landed there or at Gibraltar, though he landed at Oporto, Lisbon, and Havre. More recently he was fishing off the West Coast of Scotland and the north of Ireland. He enjoyed excellent health until the end of August, 1907, when his hands became red and swollen. After three days there was swelling of the legs, with pains in the calves, but without redness at that time. The swelling spread Irom the hands upwards and about five days after the commencement of the attack he noticed that his face was red and swollen. After the swelling was fairly developed there were repeated attacks of chilliness up to the time of admission, but there was no shivering at the onset. There were some depression and restlessness and there was slight aching in the limbs in association with the swelling; but there was no acute pain, numbness, tingling, or burning, though there was troublesome headache. The patient was admitted to the Glasgow Royal Infirmary on Sept. 3rd, 1907, eight days after the onset.

Regarding the past history of the case the patient did not remember to have ever been laid up with illness except that he might have been for a day or two in bed with a bad "cold" in his boyhood. He denied any venereal infection and there was no evidence of urethritis or of venereal ulcer or scar. He had been getting a varied diet, including beef (fresh and salted), vegetables (cabbage and potatoes), rice in moderate quantity, tea, bread, butter and fresh fish shaddock, hake, herring, plaice, and halibut). He was a total abstainer but he smoked five ounces or more of tobacco weekly. He had never seen any similar ailment before either in his own boat or about the port of Aberdeen where his headquarters were. He said that the cabin of the trawler was roomy. Further investigation threw no additional light on the etiology. He never had had sore throats except when he had had a "cold," and in any case he had none for a long time before his present illness. The exposure connected with his occupation had not been greater of late than it had been for many years. He said that there was no trouble with fleas or bed-bugs on the boat. He himself was not troubled with fleas or lice and his clothing was very clean when he came to the infirmary. There was no vomiting except after the administration of castor-oil and no history pointing to pharyngitis or gastroduodenal inflammation was forthcoming. The fauces and the tongue were normal, the teeth were in a satisfactory condition, and there $w$ s no lead line on the gums. The patient's parents were dead, but his four brothers and seven sisters were all living and were healthy.

On admission the patient presented the appearance of a strongly built man. On the face and the neck there were swelling and redness which were limited above by an abrupt margin corresponding nearly to the border of the hairy scalp, and below by a line which would nearly correspond to the neck of the jersey. The swollen skin was very firm, so that considerable pressure was required to cause pitting. The redness disappeared on pressure. The forearms and the hands were in a somewhat similar condition, but the oedema was more marked and there was considerable pitting on pressure. On the upper arms, the shoulders, and the back, and over the pectoral muscles, there were irregular patches and spots of erythema, which were raised above the general surface. This redness conld be completely removed by pressure. There was no recognisable oedema of the trunk. In the lower limbs, in almost their whole length, there was a diffuse erythema which disappeared on pressure. The reddened area was slightly elevated and there was no pitting: on pressure here. Below the knees the skin was roughened and it showed slight branny desquamation. The heart and lungs were normal and no enlargement of the liver or spleen could be recognised. There was slight enlargement of some glands in the axillæ and the groins. There was slight tenderness of muscles in the forearms and the calves.

The temperature reached $102 \cdot 2^{\circ} \mathrm{F}$. on the day of admission and it showed a distinct febrile tendency for nearly a fortnight afterwards. In the beginning of November a slight degree of fever returned and it lasted for about a fortnight. This was associated with a return of the erythematous eruption on the face, the neck, and the limbs, and to a small extent on the back. In some parts it was diffuse, in others patchy. The patient had at times, but not always, a sense of heat in the erythematous parts. These parts were of a dull red colour and the redness did not disappear completely on pressure. There was no soreness of the throat. Until a week before he was dismissed on April 7th the evening temperature would every now and then rise a few points above the normal line. At no time was there any striking disturbance of the pulse, though it was, of course, accelerated when fever was present.

On the day of admission there was a faint trace of albumin in the urine. There was again a faint trace on Sept. 27th. Albumin was more constantly present during a period beginning about the time when the fever and the rash recurred, although even then it usually amounted to a mere trace. In January and during later months it was usually absent.

An examination of the blood on the day of admission gave the following results: red corpuscles, 5,456,000 per cubic millimetre; white corpuscles, 7,200 per cubic millimetre hæmoglobin, 100 per cent. ; and colour index, 0.9. Stained films showed no abnormality. The blood was repeatedly examined bacteriologically and found to be sterile, though, on one occasion, a diplococcus was found. Blood taken from a spot of eruption on the chest proved to be sterile.

Eight days after admission the erythema and oedema had disappeared. A systolic murmur had now been recognisable for some days over the cardiac area generally, but there was no obvious enlargement of the heart and no distress. The conjunctivæ were now congested and photophobia was present. There was pain in the calves and the feet and the nerves in these parts were tender. On Sept. 14th tenderness was noted in the calves, the feet, and the toes, and also in the posterior tibial nerves behind the malleoli; but sensation (touch, pain, temperature) was still acute. On the 23rd it was recorded that there was a good deal of muscular wasting in the legs. There was considerable tenderness in the right calf and slight tenderness in the left. The knee-jerks were present and were sometimes active and sometimes sluggish. There was still some tenderness of nerves in the feet. $\mathbf{B y}$ the 27th the cardiac murmur had ceased to be audible. The apex beat was in its normal situation. On Oct. 3rd an area of anæsthesia was discovered in the lower part of the right leg. About this time the pains were practically confined to the toes of the right foot and were diminishing.

An electrical examination made by Mr. J. R. Riddell on Oct. 11th showed that muscular contraction was produced by stimulation of nerve-trunks by either current, the response being, however, much diminished in the legs and slightly so in the arms. When the electrode was applied to the muscles of the legs there was no contraction, either to faradism or to galvanism, with the strongest current the patient could bear. On Oct. 12th an extremely short systolic mitral and tricuspid murmur was heard. It was noted that both knee-jerks were decidedly reduced.

On Nov. 11th the following observations were made: "The grasp is very defective in each hand and there is wasting of the small muscles. There is slight defect of movement of the wrist. There is no dropsy in the hands at present and any other vaso-motor phenomenon is difficult to recognise on account of the colour of the skin. Detailed examination of 
[FEB. 20, 1909.

the right hand shows loss of tactile sensation in the territory of the ulnar nerve on the dorsal surface and this loss extends two-thirds of the way up the forearm. There is very slight impairment of the senses of pain and temperature in the same nerve territory. The sense of posture and the stereognostic sense are preserved. There is slight tenderness of the first interosseous muscle and also of the paim of the hand and of the ring finger. The calves of the legs have a wasted appearance; the girth of the right is $11 \frac{1}{4}$ inches, of the left $11_{4}^{3}$ inches. There is slight cedema of the dorsum of each foot. Detailed examination of the right lower limb shows that the senses of pain, touch, and temperature are defective as high up as the knee, and on the outer aspect of the thigh. The foot and toes are tender on pressure, the calf slightly so. The movement of the toes is considerably reduced. The knee-jerks are difficult to obtain, though not absolutely lost." The evidence of neuritis was in the main similar in the limbs of the two sides. Repeated blood counts made about this time gave practically normal results. The fundi oculorum were likewise normal.

In the middle of February the patient had so far recovered that he was able to move about a little, but there was still well-marked muscular atrophy, particularly in the right hand; and the legs were still thin and weak. There was still tenderness of the muscles and the nerves, particularly in the right lower limb; and sensation was somewhat defective. There was some faint brown staining in the upper limbs and on the back, representing the old cutaneous eruption.

On March 19th there was still dull-red staining on the back of the trunk, which became brown on pressure. Both knee-jerks were present, though the right was sluggish. The girth of the right calf was $11 \frac{7}{8}$ inches and of the left $12 \frac{1}{2}$ inches.

On April 6th, the day before dismissal, the patient was practically well, but there was still a little tenderness on pressure of the right sole. The knee-jerks were both well marked. The only sensory defect discovered was a reduction of painful sensation in the right leg. There were still slight traces of the rash on the back of the trunk, and there was a little defect in the bulk of the muscles of the left hand.

Three features of this case are worthy of special note : (1) the Scandinavian origin of the patient ; (2) the fact that the disease seems to have originated while the patient was sailing off the shores of Great Britain ; and (3) the association of an erythematous eruption with the more familiar symptoms of beri-beri.

1. I know of no satisfactory explanation of the frequent occurrence of beri-beri among Scandinavian crews. The theory which has been proposed that the condition is really scurvy with peripheral neuritis is quite untenable in the present case not only because the diet was good but because the usual symptoms of scurvy were absent.

2. The beri-beri of temperate climates is met with chiefly, if not solely, in ships and asylums. It is rare in Europe, but it will be remembered that an outbreak occurred in the Richmond Asylum at Dublin some 15 years ago, and Manson and Daniels state that to their own knowledge the disease has originated in the Port of London among the crews of ships that had been in harbour for several months. ${ }^{1}$

3. The occurrence of this particular kind of erythematous eruption in such close association with the attack of beri-beri seems to be new to the literature. So high an authority as Manson remarks that beri-beri is not accompanied by an eruption. ${ }^{2}$ The late Mr. Conolly Norman, however, speaking of the Richmond Asylum cases, said that one patient had a series of herpetic patches which turned into bullæ and left little ulcers behind them, and that three or four cases were ushered in by an eruption which he could not distinguish from erythema nodosum. ${ }^{3}$

When one bears in mind the variety of diseases (including infections such as rheumatism, pneumonia, and polioencephalitis) which may be associated with an eruption of the exudative erythema type it is not surorising that a cutaneous eruption more or less akin to that type should be observed in an occasional case of beri-beri.

Glasgow.

1 Allbutt and Rolleston: System of Melicine, 1907, vol. ii., Part II., p. 616 .

\section{SOME NOTES ON THE INTERPELVI- ABDOMINAL AMPUTATION, WITH A REPORT OF THREE CASES.}

By J. HOGARTH PRINGLE, M.B. EdIN., F.R.C.S. EnG., SURGEON TO THE ROYAL INFIRMARY, GLASGOW.

I AM induced to publish the following notes on the subject of the interpelvi-abdominal amputation and to report the histories of three patients upon whom I performed this operation, partly because $I$ have not been able to find any record of similar cases in British literature, and partly becanse there are some points of great importance with reference to the operation, regarding which there is some difference of opinion. As a matter of fact, the operation does not appear to have been carried out more than a few times. I can only find references to 21 cases recorded.

The first case to be published seems to have been that of Jaboulay and some of the writers on the subject speak of the operation as "Jaboulay's operation," but actually the first operation of the kind was done by Billroth; his patient died and no report of the operation was ever published, and it is only known of through a verbal communication of Professor Berg, who was present at the operation, to Professor Girard, who recorded the first instance of a patient surviving the operation. In this case Girard made a re-amputation on account of the recurrence of a sarcoma in the pelvic bones following upon a former disarticulation at the hip-joint, the disease originally being in the upper third of the femur.

The indications for the operation are, in the first place, malignant neoplasms, and in the second place, certain infective processes involving the pelvic bones. It will be more satisfactory to speak of the two conditions separately. The only form of malignant growth which is in question is

Operations for Sarcoma.

\begin{tabular}{|c|c|c|c|c|}
\hline No. & Date. & Operator. & Result. & Reference. \\
\hline 1 & $\begin{array}{c}1889 \\
\text { or } \\
1891\end{array}$ & Billroth. & $\begin{array}{l}\text { Died after a few } \\
\text { hours. }\end{array}$ & $\begin{array}{l}\text { Savariaud, Revwe de Ohi- } \\
\text { rurgie, September, 1902. }\end{array}$ \\
\hline 2 & 1894 & Jaboulay. & Died next day. & $\begin{array}{c}\text { Lyon Médieale, } 1894, \\
\text { p. } 507 .\end{array}$ \\
\hline 3 & 1895 & Jaboulay. & $\begin{array}{c}\text { Died } 36 \text { hours } \\
\text { later. }\end{array}$ & Province Med., 1895 \\
\hline 4 & $?$ & Jaboulay. & Died 5 days later. & $\begin{array}{l}\text { Verbal communication to } \\
\text { Professor Girard. }\end{array}$ \\
\hline 5 & 1894 & Cacciopoli. & Died 3 hours later. & Ruforma Medica, 1894. \\
\hline 6 & 1895 & Gayet. & Died 1 hour later. & Province Med., 1894. \\
\hline 7 & 1895 & Girard. & Survived. & Revue de Chirurgie, 1895 ? \\
\hline 8 & 1897 & Girard. & Survived. & Revue de Chirurgie, 1898. \\
\hline 9 & 1899 & Faure. & $\begin{array}{l}\text { Died ; operation } \\
\text { abandoned. }\end{array}$ & Savariaud, loc. cit. \\
\hline 10 & 1899 & Freeman. & Survived. & Aunals of Surgery. \\
\hline 11 & 1900 & Nanu. & $\begin{array}{c}\text { Survived; died } \\
20 \text { th day ; gangrene. }\end{array}$ & Revue de Chirurgie, 1900 . \\
\hline 12 & 1900 & Salistcheff. & Survived. & $\begin{array}{l}\text { Archiv fürr Klinisehe } \\
\text { Chirurgie, } 1900 .\end{array}$ \\
\hline 13 & 1901 & Savariaud. & Died 2 hours later. & Revue de Chirurgie, 1902. \\
\hline 14 & 1901 & Gallet. & Died 1 hour later. & $\begin{array}{l}\text { Annales de la Société } \\
\text { Belge de Chirurgie, } 1901 .\end{array}$ \\
\hline 15 & 1902 & Morestin. & Died 9 hours later. & $\begin{array}{l}\text { Bulletins et Mémoires de la } \\
\text { Société Anatomique de } \\
\text { Paris, 1902. }\end{array}$ \\
\hline 16 & 1903 & $\begin{array}{l}\text { Keen and } \\
\text { Da Costa. }\end{array}$ & Died 33 hours later. & $\begin{array}{l}\text { International Clinies, } \\
\text { vol. iv., Series xiii. }\end{array}$ \\
\hline 17 & ? & Kadjan. & Died. & $\begin{array}{l}\text { Kocher's Operative Sur- } \\
\text { gery, fourth edition. }\end{array}$ \\
\hline 18 & $?$ & Kocher. & Died. & $\begin{array}{l}\text { Kocher's Operative Sur* } \\
\text { gery, fourth edition. }\end{array}$ \\
\hline
\end{tabular}

Operations for Tubereulosis.

\begin{tabular}{|c|c|c|c|c|}
\hline 19 & 1895 & Girard. & $\begin{array}{c}\text { Died } 50 \text { minutes } \\
\text { later. }\end{array}$ & Revue de Chirurgie, 1898. \\
\hline 20 & 1897 & $\begin{array}{l}\text { Barden- } \\
\text { heuer. }\end{array}$ & Survived. & $\begin{array}{l}\text { Verhandlungen der Deu } \\
\text { schen Gesellschaft } \\
\text { Chirurgie, 1897. }\end{array}$ \\
\hline & 1900 & Gallet. & Died 6 hours later. & Journal de Chirurgie, 19 \\
\hline
\end{tabular}

